\title{
A Common Type of the Spectrin $\alpha$ l 46-50a-kD Peptide Abnormality in Hereditary Elliptocytosis and Pyropoikilocytosis Is Associated with A Mutation Distant from the Proteolytic Cleavage Site
}

\author{
Evidence for the Functional Importance of the Triple Helical Model of Spectrin
}

\begin{abstract}
Patrick G. Gallagher, ${ }^{\star}$ William T. Tse, ${ }^{\star}$ Theresa Coetzer, ${ }^{\ddagger \ddagger}$ Marie-Christine Lecomte, ${ }^{8}$ Michel Garbarz, Harold S. Zarkowsky," Andre Baruchel," Samir K. Ballas, "* Didier Dhermy, Jiri Palek, ${ }^{\ddagger}$ and Bernard G. Forget* *Department of Pediatrics, Human Genetics and Internal Medicine, Yale University School of Medicine, New Haven, Connecticut 06510; ${ }^{\ddagger}$ Department of Biomedical Research, Saint Elizabeth’s Hospital, Tufts University School of Medicine, Boston, Massachusetts 02135; ${ }^{\S}$ Institut National de la Santé et de la Recherche Médicale (INSERM) U160, Hôpital Beaujon, 92118 Clichy, France; "Department of Pediatrics, Washington University School of Medicine, St. Louis, Missouri 63110; "Hôpital St. Louis, 75475 Paris, 10, France;

**Department of Medicine, the Cardeza Foundation for Hematologic Research, Thomas Jefferson University, Philadelphia, Pennsylvania 19107; and ${ }^{\ddagger \ddagger}$ Department of Haematology, South African Institute for Medical Research, University of the Witwatersrand, Johannesburg 2193, South Africa
\end{abstract}

\begin{abstract}
We studied nine individuals from five unrelated families with $\alpha \mathrm{I} / 46-50 a$ hereditary elliptocytosis (HE) or hereditary pyropoikilocytosis (HPP), including one of the original HHP probands first reported by Zarkowsky and colleagues (1975. Br. J. Haematol. 29:537-543). Biochemical analysis of erythrocyte membrane proteins from these patients revealed, as a common abnormality, the presence of the $\alpha I / 46-50$ a peptide after limited tryptic digestion of spectrin. The polymerase chain reaction was utilized to study the structure of the DNA encoding the $\alpha$ I domain of spectrin in the affected individuals. The DNA sequence of the $\alpha$-spectrin gene encoding the region of the $\alpha$ spectrin chain surrounding the abnormal proteolytic cleavage site was normal. We identified a point mutation causing the replacement of a highly conserved leucine residue by proline at position 207 in the $\alpha$-spectrin chain, a site 51 residues to the amino-terminal side of the abnormal proteolytic cleavage site. Analysis of the proposed triple helical model of spectrin repeats reveals that the mutation occurs in helix 2 at a position directly opposite the abnormal proteolytic cleavage site in helix 3 , making this the first report of a mutation occurring in helix 2 of a repeat in the $\alpha \mathrm{I}$ domain of spectrin. These results add to the molecular heterogeneity of mutations associated with HE/ HPP and provide further support for the proposed triple helical model of spectrin. Disruption of this proposed $\alpha$-helical structure by helix-breaking proline substitutions may result in a functionally defective spectrin chain. (J. Clin. Invest. 1992. 89:892-898.) Key words: DNA sequence - erythrocyte membrane skeleton • hemolytic anemia • polymerase chain reaction
\end{abstract}

Portions of this work were presented at the 31st Annual Meeting of the American Society of Hematology, December 1990 and have been published in abstract form (1990. Blood. 76[Suppl.]1:7a).

Address reprint requests to Dr. Forget, Hematology Section, Department of Medicine, Yale University School of Medicine, 333 Cedar Street, P.O. Box 3333, New Haven, CT 06510.

Received for publication 17 July 1991 and in revised form 28 October 1991.

J. Clin. Invest.

(C) The American Society for Clinical Investigation, Inc.

0021-9738/92/03/0892/07 \$2.00

Volume 89, March 1992, 892-898

\section{Introduction}

The erythrocyte membrane skeleton is a network of proteins on the inner surface of the red cell membrane that is responsible for maintaining the shape and deformability of the erythrocyte (1-3). The principal proteins of the erythrocyte membrane skeleton include spectrin, ankyrin, protein 4.1, and actin (4). The major component of the erythrocyte membrane skeleton, spectrin, is composed of two structurally homologous but nonidentical proteins, $\alpha$ - and $\beta$-spectrin. $\alpha$ - and $\beta$-Spectrin intertwine to form heterodimers, which in turn self-associate in a head-to-head configuration to form tetramers and larger oligomers (5). These higher order tetramers and oligomers of spectrin appear to be critical for erythrocyte membrane stability as well as erythrocyte shape and function.

Hemolytic anemias due to qualitative and quantitative defects in the erythrocyte membrane skeleton proteins, including spectrin, are an important group of hereditary anemias. Hereditary elliptocytosis (HE) ${ }^{1}$ and hereditary pyropoikilocytosis (HPP) are two of these disorders (for reviews, see references 6-9). HE, characterized by the presence of elliptically shaped erythrocytes in the peripheral blood, is a clinically heterogeneous group of disorders ranging from the asymptomatic carrier state to severe, symptomatic hemolytic anemia. HPP, as originally described by Zarkowsky et al. (10), is an uncommon, severe hemolytic anemia characterized by abnormal erythrocyte sensitivity to heat and erythrocyte morphology reminiscent of that seen in patients after a thermal burn. HE and HPP share a number of biochemical and molecular defects, particularly abnormalities in $\alpha$ spectrin (11-13).

After limited digestion with trypsin and two-dimensional polyacrylamide gel electrophoresis, normal spectrin can be resolved into five $\alpha$ and four $\beta$ proteolytically resistant domains $(14,15)$. The amino terminus of $\alpha$-spectrin, the $\alpha$ I domain, interacts with the carboxy terminus of $\beta$-spectrin, the $\beta \mathrm{I}$ domain, to form the oligomer binding site for heterodimer self-association. Defects in the $\alpha \mathrm{I}$ domain have been identified in a subset of patients with HE and HPP that lead to structural and functional abnormalities in spectrin. In these patients, limited tryptic digestion of mutant spectrins has revealed abnormal or enhanced proteolytic cleavage of the $80-\mathrm{kD}$ fragment of the $\alpha \mathrm{I}$

1. Abbreviations used in this paper: ASO, allele-specific oligonucleotide; HE, hereditary elliptocytosis; HHP, hereditary pyropoikilocytosis; PCR, polymerase chain reaction. 
domain with the generation of fragments of $78,74,65-68,61$, $46-50 \mathrm{a}, 50 \mathrm{~b}$, and $43 \mathrm{kD}$ (reviewed in references 6-9). In some cases, amino acid and DNA sequencing has identified mutations near the sites of abnormal or enhanced proteolytic cleavage (16-22).

This study describes the characterization of a common mutation found in nine individuals from five unrelated kindreds with $\alpha \mathrm{I} / 46-50$ a (also referred to as $\mathrm{Sp} \alpha \mathrm{I} /{ }^{46-50 a}$ ) HE or HPP including one of the HPP probands originally described by Zarkowsky et al. (10). This mutation occurs at some distance from the abnormal proteolytic cleavage site. Analysis of the proposed triple helical model of spectrin repeats reveals that the mutation occurs in helix 2 in a position directly opposite the abnormal proteolytic cleavage site in helix 3 , making this the first report of a mutation occurring on helix 2 of the $\alpha$ I domain of spectrin.

\section{Methods}

Erythrocyte deformability and membrane stability. These studies were performed by using an ektacytometer. Whole-cell deformability was followed as a function of the osmolality of the suspending medium as previously described (23). The membrane resistance to sheer-induced fragmentation was measured as described (24).

Erythrocyte membrane preparation and quantitation of spectrin content. Red cell membranes were prepared as described (21). Membrane proteins were analyzed by electrophoresis in SDS-PAGE either with a 5-15\% polyacrylamide gradient as described by Laemmli (25) or using a 3.5\% polyacrylamide gradient as described by Fairbanks et al. (4). To estimate spectrin/band-3 ratios, SDS polyacrylamide slab gels (4) were scanned after Coomassie Blue staining using a DU8 spectrophotometer (Beckman Instruments, Inc., Fullerton, CA) at $550 \mathrm{~nm}$.

Study of spectrin dimer-tetramer equilibrium. Spectrin was extracted by incubating white ghosts overnight at $4^{\circ} \mathrm{C}$ in low ionic strength buffer (26). The content of spectrin dimers and tetramers was determined by nondenaturing gel electrophoresis as described $(27,28)$.

Limited trypic digestion of spectrin. Limited tryptic digests of spectrin were prepared as described (21). Spectrin peptides were separated by SDS-PAGE in a 7-15\% polyacrylamide gradient and by two-dimensional electrophoresis as described by O'Farrell (29) and modified by Speicher et al. (14). One-dimensional SDS-PAGE gels of spectrin tryptic digests were scanned at $550 \mathrm{~nm}$ after Coomassie Blue staining.

Partial amino acid sequencing of SpaI/46-50a-kD peptide. After separation by SDS-PAGE, tryptic peptides were transferred onto polyvinylidene difluoride membranes (Immobilon, Millipore Corp., Bedford, MA). After staining with Coomassie Blue, the band corresponding to the $46-50 \mathrm{a}-\mathrm{kD}$ peptide was excised and destained. Microsequencing analysis was performed with a gas-phase sequencer (model 740A, Applied Biosystems, Foster City, CA) (30).

Oligonucleotide synthesis and genomic DNA amplification. Synthetic oligonucleotides were synthesized using an automated synthesizer (Applied Biosystems, Inc., Foster City, CA) and purified by gel electrophoresis or OPC column chromatography (Applied Biosystems,
Inc.). The sequences of the various primers are listed in Table I. Selected exons of the spectrin $\alpha$ I domain were amplified by the polymerase chain reaction (PCR) (31) using an automated DNA Thermal Cycler (Perkin-Elmer Cetus, Norwalk, CT), as previously described (18).

Subcloning of amplified DNA. The amplification products were either blunt-end ligated into HincII-digested pGEM4 plasmid DNA (Progema Corp., Madison, WI) using T4 DNA ligase (New England Biolabs, Beverly, MA) or digested with EcoR1 or HindIII, depending on the enzyme site incorporated into the oligonucleotide primer, and ligated into an appropriately prepared pGEM7 plasmid vector (Promega Corp., Madison, WI). The plasmid vectors were transfected into competent DH5 $\alpha$ E. coli.

Sequencing of subcloned genomic DNA. Subcloned genomic DNA fragments were sequenced by using T7 DNA polymerase (Sequenase, United States Biochemical Corp., Cleveland, $\mathrm{OH}$ ) and the dideoxy chain termination method of Sanger et al. (32).

Direct sequencing of amplified DNA. PCR-amplified products were purified by agarose gel electrophoresis and one half of the amplification products were subjected to a second round of PCR. Conditions were identical to that described above except that primers were used in a 1:50 picomolar ratio and 40 cycles of amplification were completed (33). Amplification products were passed through an Amicon 30 filter (W.R. Grace \& Co., Danvers, MA) before nucleotide sequencing. Sequence analysis was carried out using, as sequencing primer, the primer present in limiting concentration (1 pmol) in the asymetric PCR reaction.

Slot-blot hybridization. Genomic DNA was amplified by PCR using the technique outlined by Saiki et al. (34). $20 \mu$ l of the PCR reaction was transferred to a nylon membrane (Nytran, Schleicher \& Schuell, Inc., Keene, $\mathrm{NH}$ ) using a slot blot apparatus and hybridized as described with allele-specific oligonucleotide (ASO) probes containing either the normal or mutant sequence (34). The final washing step was at $60^{\circ} \mathrm{C}$ for $10 \mathrm{~min}$. The sequences of the normal and mutant probes were 5'-TTTAGCTACCAGCTCCACTTG-3' and 5'-TTTAGCTACCGGCTCCACTTG-3', respectively.

Patients. Clinical and biochemical studies of patients 1 (T.N. in references 12 and 35 ) and 2, one of the HPP probands originally described by Zarkowsky et al. (10) (M.A. in reference 36) have been previously reported. Both patients, black males, had severe hemolytic anemia requiring splenectomy early in childhood. Their erythrocytes were remarkable for extreme poikilocytosis and microspherocytosis, as well as abnormal thermal sensitivity.

Patient 3 is a 34-yr-old black woman with severe poikilocytic anemia requiring splenectomy in childhood. Her blood smear showed marked anisocytosis, poikilocytosis, fragmented red cells, microspherocytes, and some elliptocytes. Her current hematologic values are as follows: hemoglobin (Hb) $11.2 \mathrm{~g} / \mathrm{dl}$, hematocrit (Hct) $30 \%$, reticulocyte count $6.2 \%$, and mean corpuscular volume (MCV) of $61 \mathrm{fl}$. Osmotic fragility is increased.

Patient 4 is a 50 -yr-old black woman with HE. Her erythrocyte morphology is remarkable for elliptocytes, poikilocytes, and microcytes. Her hematologic values are as follows: $\mathrm{Hb} 9.6 \mathrm{~g} / \mathrm{dl}$, Hct $26 \%$, reticulocyte count of $2.3 \%$, and MCV of $78 \mathrm{fl}$. Osmotic fragility is slightly increased.

Table I. Sequences of Oligonucleotides Used for PCR Amplification of $\alpha$-Spectrin Gene Exons in Total Cellular DNA

\begin{tabular}{cll}
\hline Exon & \multicolumn{1}{c}{ Sense strand } & \multicolumn{1}{c}{ Antisense strand } \\
\hline 5 & CGGAATTCCTGGGAATGCAAGCAGGAGT & CGAAGCTTGAACCCTTTGCACGGAGTGA \\
6 & CTCATCTCTGTATAACTCCAG & AGAGCCTAATACAAAGAC \\
7 & GGTTGGAGCTCTTGTTAATG & AGCCATTTCTCTAACAGCGC
\end{tabular}

Restriction endonuclease sites for BamHI or HindIII incorporated into some of the primers are underlined. The sequences $\left(5^{\prime}\right.$ to $\left.3^{\prime}\right)$ are those of the flanking introns. 
Patient 5: the proband of this kindred is a 2-yr-old black girl with severe neonatal hemolytic anemia $(\mathrm{Hb} 7.7 \mathrm{~g} / \mathrm{dl}$, reticulocytes 500,000 / $\mathrm{mm}^{3}$ ). After excluding other causes of hemolysis, clinical and biochemical studies were consistent with the diagnosis of homozygous elliptocytosis. Her blood smear showed prominent poikilocytosis, elliptocytosis, schistocytosis, and microcytosis (MCV of $63 \mathrm{fl}$ ). Osmotic fragility was increased. Her erythrocytes were sensitive to heat treatment, with fragmentation at $45^{\circ} \mathrm{C}$; erythrocytes from control individuals did not fragment below $49^{\circ} \mathrm{C}$. Mechanical resistance of resealed ghosts was greatly decreased, estimated at $10 \%$ of the normal control. She was transfusion dependent for the first 6 mo of life. Her growth and development has been normal.

\section{Results}

Quantitation of spectrin content and study of spectrin dimertetramer equilibrium. Table II shows the results of analysis of erythrocyte membrane proteins, as estimated by spectrin/band 3 ratios, and impairment of spectrin dimer self-association, as evidenced by increased amounts of spectrin dimers in $4^{\circ} \mathrm{C}$ spectrin extracts, from patient 5 and members of her family. The spectrin/band 3 ratio was markedly decreased in patient 1 (12), not done in patient 2 (36), 0.78 in patient 3 (control $1.0 \pm 0.1$ ), and 0.97 in patient 4 . Spectrin dimer in extracts was $30 \%$ in patient 1 (35), increased in patient $2(36), 59 \%$ in patient 3 , and $37 \%$ in patient 4 . Other erythrocyte membrane proteins were quantitatively normal.

Erythrocyte deformability and membrane stability. Ektacytometric analysis was performed using erythrocytes from patients 3 and 5 . Erythrocytes from patient 3 exhibited markedly decreased erythrocyte deformability. In patient 5 , osmotic gradient ektacytometry showed decreased red cell deformability with an ektacytometric profile similar to that observed in severe hereditary spherocytosis.

Limited tryptic digestion of spectrin. One-dimensional polyacrylamide gel electrophoresis of spectrin following limited tryptic digestion revealed new peptides of $46-50 \mathrm{a}$ and $21 \mathrm{kD}$ and no normal $80-\mathrm{kD}$ peptide in patient 5 (Fig. 1). Digests from four asymptomatic, elliptocytic family members of patient 5 showed the presence of the $46-50 \mathrm{a}-\mathrm{kD}$ peptide and decreased normal 80 -kD peptide $(\sim 50 \%)$ (Fig. 1). One- and two-dimensional gels from patients 1 (35), 2 (36), and 3 (data not shown) revealed the presence of the mutant $46-50 \mathrm{a}-\mathrm{kD}$ peptide as well as virtual absence of the normal $80-\mathrm{kD} \alpha \mathrm{I}$ domain spectrin peptide. Gels from patient 4 showed the presence of the mutant $46-50 \mathrm{a}-\mathrm{kD}$ peptide and decreased normal $80-\mathrm{kD}$ peptide (not

Table II. Quantitation of Spectrin Content and Study of Spectrin Dimer-Tetramer Equilibrium

\begin{tabular}{lcc}
\hline \multicolumn{1}{c}{ Patient } & $\begin{array}{c}\text { Quantitation of } \\
\text { spectrin content } \\
\text { (spectrin/band 3 ratio) }\end{array}$ & $\begin{array}{c}\text { Dimer-tetramer } \\
\text { equilibrium (percentage of } \\
\text { spectrin dimer in extracts) }\end{array}$ \\
\hline Control & $1.04 \pm 0.13$ & $3.6 \pm 0.4$ \\
5-proband & 0.85 & 44 \\
5-mother & 1.03 & 7.5 \\
5-father & 0.84 & 8.5 \\
5-aunt & 1.13 & 9.5 \\
5-brother & Not done & 5 \\
\hline
\end{tabular}

shown). Immunoblots using anti-80-kD peptide antibody revealed the presence of a small amount of the normal $80-\mathrm{kD}$ peptide in patient 3 .

Partial amino acid sequencing of the spectrin $\alpha I$ 46-50a-kD peptide. Partial amino acid sequencing of the $\alpha \mathrm{I} / 46-50 \mathrm{a}-\mathrm{kD}$ peptide from patient 5 demonstrated that abnormal cleavage occurred after lysine $258 .{ }^{2}$ Previously reported $\alpha \mathrm{I} / 46-50 \mathrm{a}-\mathrm{kD}$ abnormalities have been associated with trypsin cleavage after arginine $256(\alpha \mathrm{I} 260$, Lys to Pro) and after lysine $252(\alpha 261$, Ser to Pro) (16).

$P C R$ amplification and DNA sequencing. Analysis of subcloned fragments revealed that the DNA sequence of $\alpha$ spectrin exon 6 , the region encoding the $\alpha \mathrm{I} / 46-50 \mathrm{a}$ cleavage site, was normal in all five patients. 18 subclones from patient $1(18)$ and 20 subclones from patient 2 (37) were analyzed. Direct sequencing of PCR-amplified exon 6 from genomic DNA of patients 3,4 , and 5 revealed a normal sequence.

Sequence analysis of subcloned PCR-amplified DNA fragments encoding $\alpha$ spectrin exon 5 from patients 1 and 2 revealed a single nucleotide substitution at codon position 207 CGT (leucine) to CㅡG (proline) (Fig. 2 a). This substitution was present in 10 of 10 subclones in patient 1 and in 3 of 12 subclones in patient 2 . Direct sequencing of PCR-amplified exon 5 revealed heterozygosity for the same mutation in patients 3 (Fig. $2 b$ ) and 4 and homozygosity for the mutation in patient 5. The affected amino acid residue (no. 207) of the $\alpha$-spectrin chain is located in the second typical repeat of the $\alpha$-spectrin chain at position 79 of the repeat (38), near the middle of helix 2 in the proposed triple helical model of Speicher and Marchesi (39). A number of point mutations due to proline substitutions have been identified in the spectrin from $\mathrm{HE}$ and HPP patients $(16,18,37)$. Proline residues have a high propensity to disrupt $\alpha$ helices thus underscoring the importance of the proposed $\alpha$ helical conformation in the structure of spectrin chains.

Direct nucleotide sequencing of exon 7 in patients 1 and 2 revealed a single nucleotide change at position 299 , AGC to AGT, which does not change the encoded amino acid residue (serine). This change probably represents a silent polymorphism.

Restriction enzyme digestion and slot blot analysis. The authenticity of this mutation was confirmed by restriction enzyme digestion and allele specific oligomer hybridization of amplified DNA from separate PCR reactions. The nucleotide substitution at codon 207 creates an MspI restriction site, CCGG, facilitating detection of this mutation. Digestion of amplification products of exon 5 with MspI cleaves the normal fragment of $289 \mathrm{bp}$ into fragments of 183 and $106 \mathrm{bp}$. Analytical digestion shows homozygosity for this mutation in patients 1 and 5, heterozygosity in the seven other HE or HPP individuals, and no digestion in control subjects (Fig. 3).

The presence of this nucleotide substitution was also confirmed by ASO hybridization. Patients 2, 3, and 4 had both the normal and mutant alleles whereas patients 1 and 5 had only the mutant allele (data not shown).

2. This numbering system is based on the translated amino acid sequence of $\alpha$-spectrin cDNA (38), which includes six additional amino acid residues compared to previous reports that numbered amino acids from the first amino acid of the $\alpha \mathrm{I} / 80-\mathrm{kD}$ domain (15). 


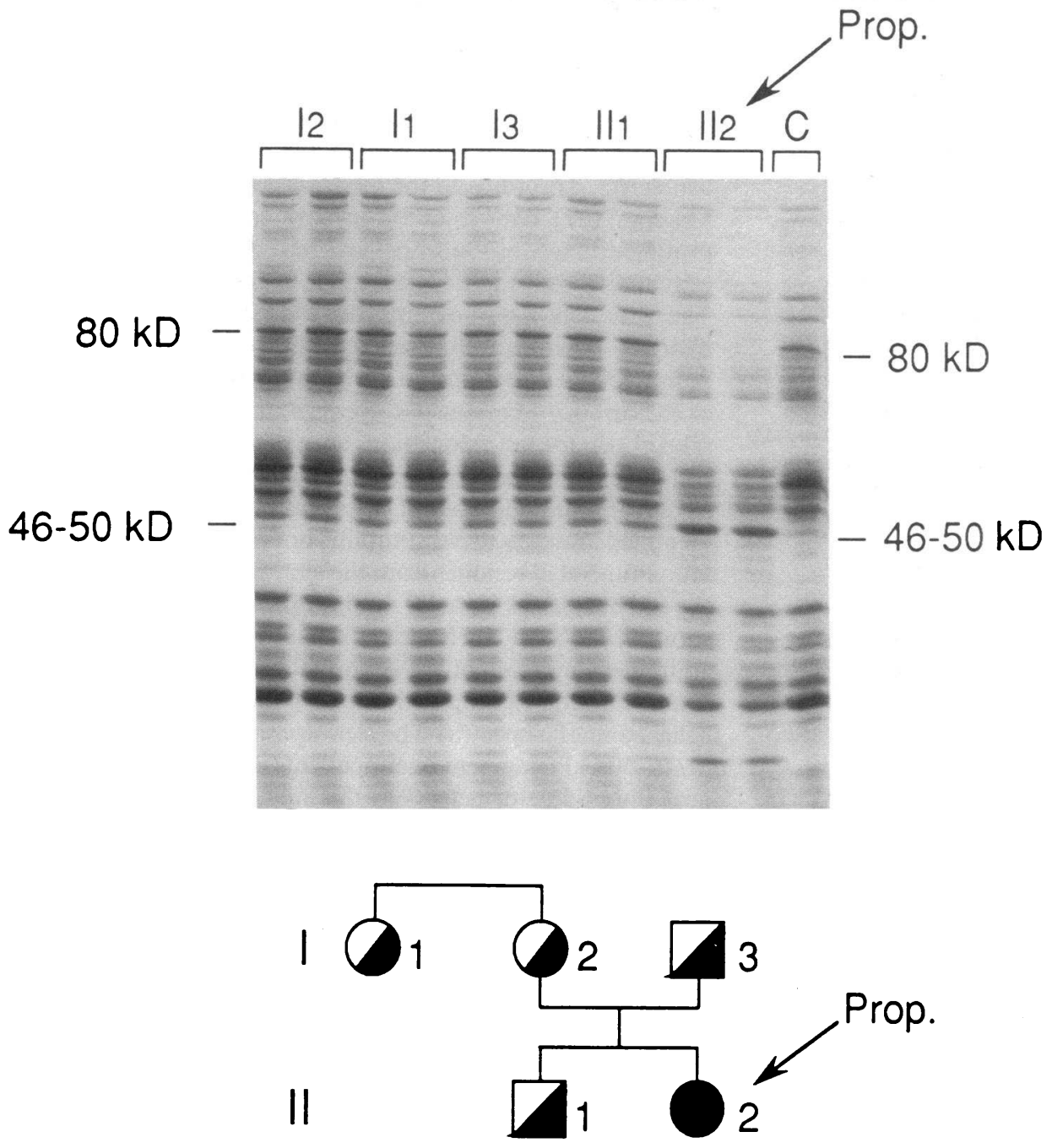

Figure 1. Limited tryptic digestion of spectrin. One-dimensional SDS PAGE of limited tryptic digests of erythrocyte spectrin from patient 5 and her family members. Bands representing both the normal $80-\mathrm{kD}$ peptide of the $\alpha \mathrm{I}$ domain of spectrin and the abnormal $46-50 \mathrm{a}-\mathrm{kD}$ peptide are noted in digests from the parents of patient 5, a maternal aunt, and a sibling. Digests from patient 5 (II 2 ) contain only the mutant $46-50 \mathrm{a}-\mathrm{kD}$ peptide and no normal $80-\mathrm{kD}$ peptide. $\mathrm{C}$ is a normal control.

\section{Discussion}

HE and HPP are two disorders that share a number of clinical, biochemical and molecular abnormalities (6-13). Approxi- mately one third of the parents or siblings of HPP patients have typical HE, and in many infants with HPP, the disorder evolves into typical HE with time (13). Erythrocytes from patients with both conditions often exhibit thermal and mechanical instabil-

a

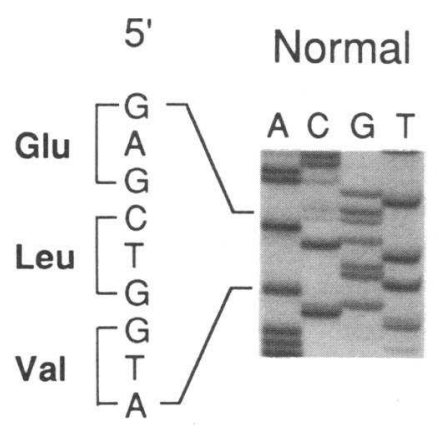

$3^{\prime}$
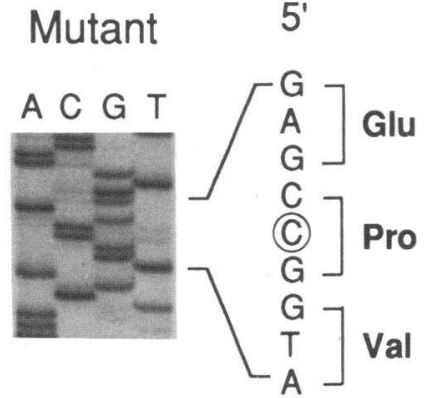

$3^{\prime}$ b

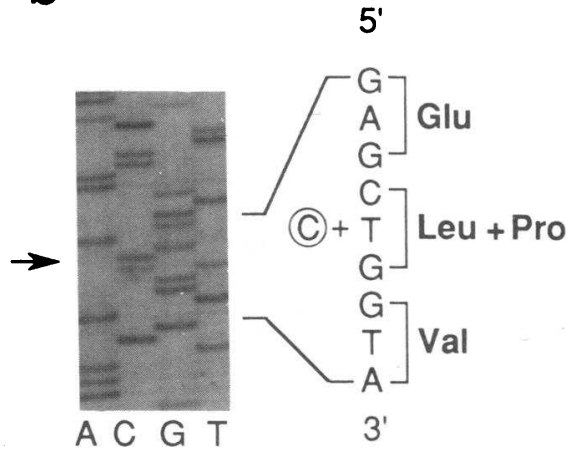

Figure 2. Nucleotide sequence of PCR-amplified DNA of patients with HE or HPP and the $\alpha \mathrm{I} / 46-50 \mathrm{a}-\mathrm{kD}$ abnormality. Genomic DNA encoding exon 5 of the $\alpha$-spectrin gene was amplified by PCR. (a) A point mutation, CIG to CG, which changes a leucine to a proline, is demonstrated in a mutant subcloned amplification product of patient 2 who is heterozygous for the mutation; the normal subclone was obtained from the same patient. $(b)$ The same mutation is demonstrated in the heterozygous state in directly sequenced amplification products of patient 3 after asymetric PCR of DNA. 


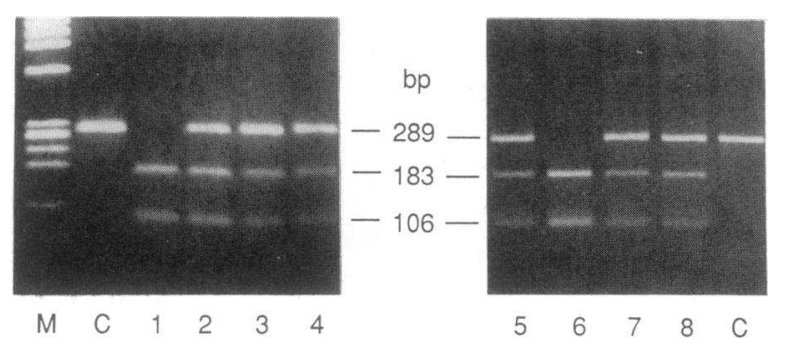

Figure 3. Restriction endonuclease digestion of PCR-amplified DNA. Genomic DNA encoding exon 5 of the $\alpha$-spectrin gene was amplified by PCR and digested with MspI. There is no digestion of control (C) amplification products. Lane 1, patient 1; lane 2, patient 2; lane 3, patient 3; lane 4, patient 4; lane 5, brother of patient 5 ; lane 6 , patient 5 ; lanes 7 and 8 , father and mother, respectively, of patient 5. Patients 1 and 5 are homozygous for the mutation, whereas patients $2,3,4$, and the brother and parents of patient 5 are heterozygous for the mutation.

ity (10-12). Many of the same molecular defects found in the spectrin of HE patients have been identified in HPP patients, including defective dimer self-association and structural alterations of the $\alpha \mathrm{I}$ domain of spectrin $(11-13,36)$.

HE and HPP have been classified according to the type of structural abnormality of the $\alpha$ I domain of spectrin detected after limited tryptic digestion. The subgroup associated with an abnormal $\alpha \mathrm{I} / 46-50 \mathrm{a}-\mathrm{kD}$ peptide is proving to be heterogeneous in its clinical and biochemical manifestations, as well as its molecular basis $(16,18,35-37,40)$. Clinically, affected individuals may range from asymptomatic carriers with normal hematocrits to patients with severe anemia with hemolysis requiring blood transfusion. The severity of impairment of spectrin self-association, as evidenced by percentage of spectrin dimers in extracts, varies widely in this group of patients, ranging from normal to markedly increased (12). At the molecular level, two proline substitutions, at codons 260 and 261, have been previously described in HE/HPP associated with the $\alpha \mathrm{I} /$ 46-50a-kD abnormality. The identification of the codon 207 mutation adds to the molecular heterogeneity of HE/HPP associated with the $\alpha \mathrm{I} 46-50 \mathrm{a}-\mathrm{kD}$ abnormality.

In contrast, HE/HPP associated with the $\alpha \mathrm{I} / 65-68-\mathrm{kD}$ abnormality is homogeneous at the molecular level, with all previously described cases being due to a leucine insertion between residues 154 and $156(17,18,37)$. HE/HPP associated with the $\alpha \mathrm{I} / 74-\mathrm{kD}$ abnormality has been found to be due to a number of different amino acid substitutions in $\alpha$-spectrin $(19,20,41,42)$, an amino acid substitution in $\beta$-spectrin (43), and a number of truncated $\beta$-spectrin chains (44-49).

It appears that the codon 207 proline substitution is a relatively common cause of the $\alpha$ I 46-50a-kD abnormality. Assuming that the parents of patients 1 and 5 are unrelated, then this mutation is present in seven different kindreds. All patients are of black African ancestry. To determine if there is a founder effect associated with this mutation, the status of an XbaI polymorphism in the $\alpha$ I domain of spectrin (50) was examined in amplified genomic DNA. Patients 1 and 5, who are homozygous for the codon 207 mutation, are also homozygous for the presence of the $\mathrm{XbaI}$ site, whereas patients 2, 3, and 4 are heterozygous for the RFLP and the codon 207 mutation. This result suggests that the 207 proline substitution is linked to the presence of the $\mathrm{XbaI}$ polymorphism, and that there is a common origin (i.e., a founder effect) for this mutation.

Generation of abnormal peptides from the $\alpha$ I domain after limited tryptic digestion and two-dimensional gel electrophoresis provides important clues to the site of the underlying spectrin defect. According to the model proposed by Speicher and Marchesi (39), both $\alpha$ - and $\beta$-spectrin consist mainly of a repeating structure of 106 amino acid repeats that can be theoretically folded into triple helical units, as illustrated in Fig. $4 \mathrm{~A}$. The triple helical repeats consist of alternating hydrophilic and hydrophobic regions, forming a coiled-coil structure resistant to proteolysis. Mutations in the amino terminus of $\alpha$-spectrin or the carboxy terminus of $\beta$-spectrin, the regions involved in spectrin dimer self-association, appear to disrupt this coiledcoil structure of spectrin repeats, impairing spectrin dimer selfassociation. In a number of cases, amino acid sequencing has identified amino acid substitutions or insertions within two to four amino acid residues from the abnormal proteolytic cleavage site but also as far as 29 residues (16-22). The proline substitution at codon 207 is located 51 amino acid residues to the amino-terminal side of the abnormal proteolytic cleavage site near the middle of proposed helix 2 of the second typical triple helical unit of $\alpha$-spectrin. The cleavage site that gives rise to the $\alpha \mathrm{I} / 46-50 \mathrm{a}-\mathrm{kD}$ fragment in our patients is located at codon 258 near the middle of helix 3 in this unit, opposite the proline substitution (Fig. $4 \mathrm{~B}$ ).

The importance of helix 3 of each spectrin repeat in maintaining the structural integrity over the whole length of the dimer has been emphasized $(16,19)$. A number of mutations associated with HE and HPP have been identified in the region corresponding to the proposed helix 3 in different repeats of the $\alpha$ I domain of spectrin (reviewed in reference 8 ). There have been no previous reports of mutations in the proposed helix 2 region of $\alpha$-spectrin. The substitution in our patients may disrupt the local conformation of helix 2 , disturbing the secondary structure within the helical unit and probably exposing helix 3 to enhanced proteolysis. Thus the triple helical model explains how this distant amino acid substitution may cause a conformational change and enhanced proteolytic cleavage at a considerable distance from the site of the mutation thereby giving rise to the $\alpha \mathrm{I} / 46-50$ a peptide.

This result also provides evidence that the triple helical conformation is important for maintaining the integrity of spectrin chains and indicates that a disruption of the triple helical structure may result in a functionally defective spectrin chain. However, the severity of the functional defect appears to depend on which triple helix is affected. Mutations located in the peptide segments directly implicated in the spectrin dimer self-association site lead to complete inability to form mutated homotetramers $(13,43)$. Conversely, mutations located in triple helices far from the self-association site confer only a reduced affinity to self-association, as observed in the homozygous cases reported here or, for example, in patients homozygous for the spectrin $\alpha \mathrm{I} / 68-\mathrm{kD}$ variant $(13,52)$. This long range effect could imply that these mutations reduce the strain involved in the stabilization of the normal spectrin dimer conformation.

The HPP phenotype has been associated with homozygosity for an $\alpha$-spectrin structural variant (e.g., patients 1 and 5) $(27,51,52)$, as well as double heterozygosity for two different structural variants $(36,41,53-55)$. Other cases, such as patients 2 and 3 , are associated with heterozygosity for a single struc- 

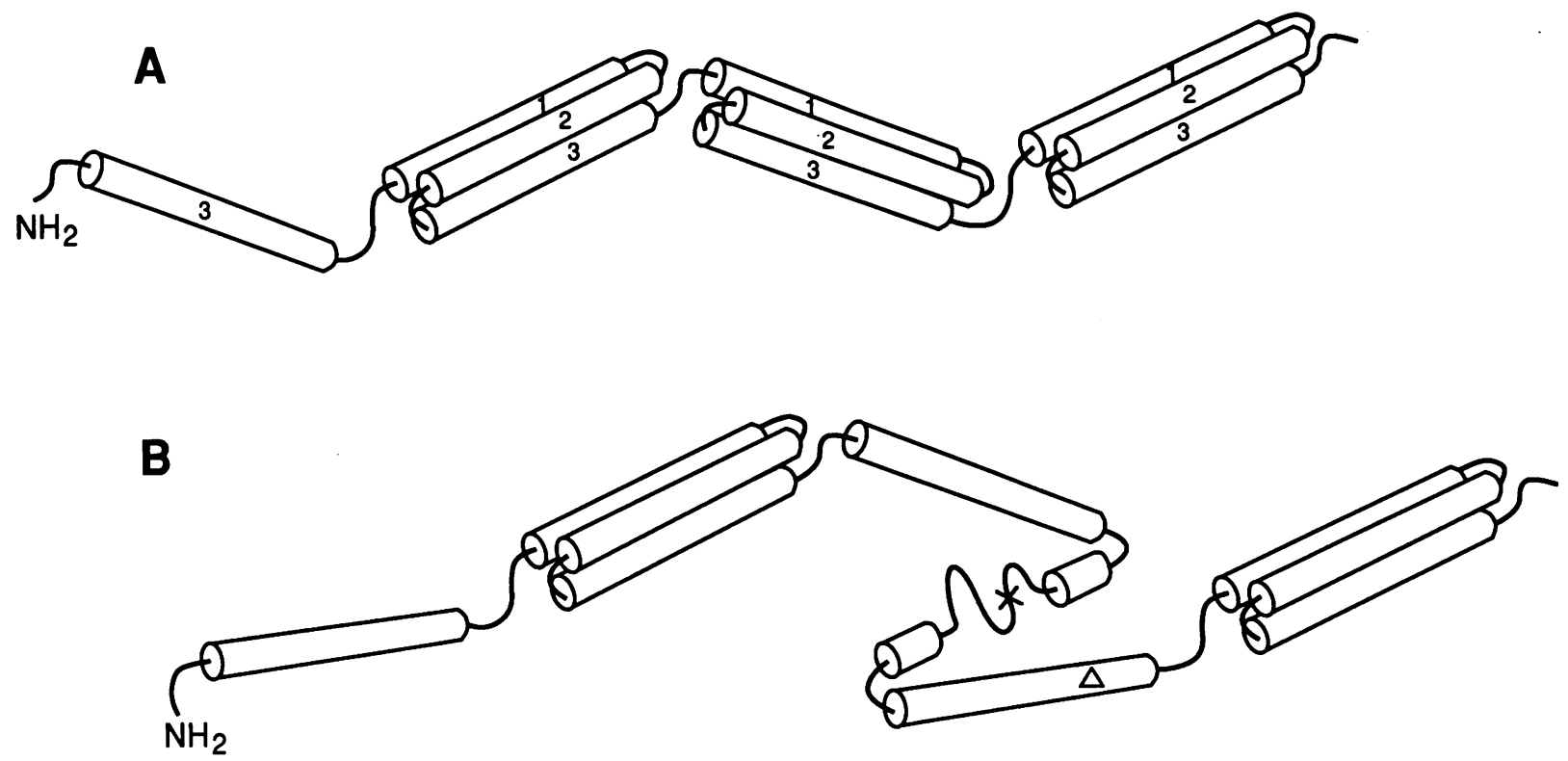

Figure 4. Model for the secondary structure of spectrin chains. $(A)$ The normal triple helical model of spectrin according to Speicher and Marchesi (39), modified by Tse et al. (43) to show the potential intrachain interaction between $\alpha$ spectrin helices. The helices are numbered as proposed by Speicher and Marchesi (39). (B) The mutation at position 207 (shown by the $X$ ) in helix 2 of the second triple segment of $\alpha$ spectrin could disrupt the structure of helix 2 , thereby exposing helix 3 in the same segment to abnormal tryptic digestion at the site designated by the triangle, thus generating the $\alpha \mathrm{I} / 46-50 \mathrm{a}-\mathrm{kD}$ peptide.

tural variant of spectrin, but marked deficiency of $\alpha$-spectrin production, as evidenced by virtual absence of the normal $\alpha \mathrm{I}$ $80-\mathrm{kD}$ peptide on tryptic maps of spectrin. Patients 2,3 , and 4 have increased spectrin dimers compared to homozygous patients and markedly increased spectrin dimers compared with other asymptomatic heterozygous $\alpha \mathrm{I} / 46-50 \mathrm{a}$ patients (e.g., family members of patient 5). These observations have led to speculation that a second defect causing decreased production of spectrin from the other allele is present in these patients $(7,8$, $55)$, leading to increased clinical severity and increased spectrin dimers in extracts. The precise nature of this thalassemia-like defect in spectrin production remains unknown, but is the subject of ongoing investigation.

\section{Acknowledgments}

We thank M. Nabors, I. Devaux, H. Gautero, and D. Bournier for skilled technical assistance and Drs. H. Cohen and T. Butler for providing blood samples from patients. We also acknowledge the contribution of J. C. Gandar (Centre National de la Recherche Scientifique, Institut de Biochimie Cellulaire et Neurochimie, Bordeaux, France) who performed partial amino acid sequencing and of the Établissement Public Regional d'Aquitaine.

This work was supported in part by grants from the National Institutes of Health, the March of Dimes Birth Defects Foundation, and INSERM, Resau Nord-Sud 489 NS 3.

\section{References}

1. Bennett, V. 1990. Spectrin-based membrane skeleton: a multipotential adaptor between plasma membrane and cytoplasm. Physiol. Rev. 70:1029-1065.

2. Marchesi, V. T. 1985. Stabilizing infrastructure of cell membranes. Annu. Rev. Cell Biol. 1:531-561.
3. Bennett, V. and S. Lambert. 1991. The spectrin skeleton: from red cells to brain. J. Clin. Invest. 87:1483-1489.

4. Fairbanks, G., T. L. Steck, and D. F. H. Wallach. 1971. Electrophoretic analysis of the major polypeptides of the human erythrocyte membrane. Biochemistry. 10:2606-2617.

5. Lui, S.-C., P. Windisch, S. Kim, and J. Palek. 1984. Oligomeric states of spectrin in normal erythrocyte membranes: biochemical and electron microscopic studies. Cell. 37:587-594.

6. Lux, S. E., and P. S. Becker. 1989. Disorders of the red cell membrane skeleton: hereditary spherocytosis and hereditary elliptocytosis. In The Metabolic Basis of Inherited Diseases. 6th edition. C. R. Scriver, A. L. Beaudet, W. S. Sly, and D. Valle, editors. McGraw-Hill Inc., New York. 2367-2408.

7. Delaunay, J., N. Alloisio, L. Morle, and B. Pothier. 1990. The red cell skeleton and its genetic disorders. Mol. Aspects Med. 11:161-241.

8. Palek, J., and S. Lambert. 1990. Genetics of the red cell membrane skeleton. Semin. Hematol. 27:290-232.

9. Gallagher, P. G., W. T. Tse, and B. G. Forget. 1990. Clinical and molecular aspects of disorders of the erythrocyte membrane skeleton. Semin. Perinatol. 14:351-367.

10. Zarkowsky, H. S., N. Mohandas, C. B. Speaker, and S. B. Shohet. 1975. A congenital haemolytic anemia with thermal sensitivity of the erythrocyte membrane. Br. J. Haematol. 29:537-543.

11. Prchal, J. T., R. P. Castleberry, R. T. Parmley, W. M. Crist, and A. Malluh. 1982. Hereditary pyropoikilocytosis and elliptocytosis: clinical, laboratory, and ultrastructural features in infants and children. Pediatr. Res. 16:484489.

12. Coetzer, T. J. Lawler, J. T. Prchal, and J. Palek. 1987. Molecular determinants of clinical expression of hereditary elliptocytosis and pyropoikilocytosis. Blood. 70:766-772.

13. Coetzer, T., J. Palek, J. Lawler, S. C. Liu, P. Jarolim, M. Lahav, J. T. Prchal, W. Wang, B. P. Alter, G. Schewitz, et al. 1990. Structural and functional heterogeneity of $\alpha$ spectrin mutations involving the spectrin heterodimer self-association site: relationships to hematologic expression of homozygous hereditary eliptocytosis and hereditary pyropoikilocytosis. Blood. 75:2235-2244.

14. Speicher, D. W., J. S. Morrow, W. J. Knowles, and V. T. Marchesi. 1980. Identification of proteolytically resistant domains of human erythrocyte spectrin. Proc. Natl. Acad. Sci. USA. 77:5673-5677.

15. Speicher, D. W., J. S. Morrow, W. J. Knowles, and V. T. Marchesi. 1982. A structural model of human erythrocyte spectrin: alignment of chemical and functional domains. J. Biol. Chem. 257:9093-9101.

16. Marchesi, S. L., J. T. Letsinger, D. W. Speicher, V. T. Marchesi, P. Agre B. Hyun, and G. Gulati. 1987. Mutant forms of spectrin $\alpha$-subunits in hereditary elliptocytosis. J. Clin. Invest. 80:191-198. 
17. Roux, A.-F., F. Morle, D. Guetarni, P. Colonna, K. Sahr, B. G. Forget, J. Delaunay, and J. Godet. 1989. Molecular basis of Sp $\alpha^{1 / 65}$ hereditary elliptocytosis in North Africa: insertion of a TTG triplet between codons 147 and 149 in the $\alpha$-spectrin gene from five unrelated families. Blood. 73:2196-2201.

18. Sahr, K. E., T. Tobe, A. Scarpa, K. Laughinghouse, S. L. Marchesi, P. Agre, A. J. Linnenbach, V. T. Marchesi, and B. G. Forget. 1989. Sequence and exon-intron organization of the DNA encoding the $\alpha$ I domain of human spectrin: application to the study of mutations causing hereditary elliptocytosis. J. Clin. Invest. 84:1243-1252.

19. Morle, L., A.-F. Roux, N. Alloisio, B. Pothier, J. Starck, J. Denoroy, F. Morle, R.-C. Rudigoz, B. G. Forget, J. Delaunay, et al. 1990. Two elliptocytogenic $\alpha^{\mathrm{l} / 74}$ variants of the spectrin $\alpha$ I domain: spectrin Culoz (GGT-GTT; $\alpha \mathrm{I} 40$ Gly-Val) and spectrin Lyon (CTT-TTT; $\alpha$ I 43 Leu-Phe). J. Clin. Invest. 86:548554.

20. Garbarz, M., M.-C. Lecomte, C. Feo, I. Devaux, C. Picat, C. Lefebvre, F. Gailbert, H. Gautero, O. Bournier, C. Galand, et al. 1990. Hereditary pyropoikilocytosis and elliptocytosis in a white French family with the spectrin $\alpha \mathrm{I} / 74$ variant related to a CGT to CAT codon change (Arg to His) at position 22 of the spectrin $\alpha$ I domain. Blood. 75:1691-1698.

21. Lecomte, M.-C., M. Garbarz, B. Grandchamp, C. Feo, H. Gautero, I. Devaux, O. Bournier, C. Galand, L. d'Auriol, F. Galibert, et al. 1989. Sp ${ }^{1 / 78}$ : a mutation of the $\alpha$ I spectrin domain in a white kindred with HE and HPP phenotypes. Blood. 74:1126-1133.

22. Morle, L., N. Allosio, M. T. Ducluzeau, B. Pothier, R. Blibech, R. Kastally, and J. Delaunay. 1988. Spectrin Tunis ( $\alpha \mathrm{I} / 78)$ : a new $\alpha \mathrm{I}$ variant that causes asymptomatic hereditary elliptocytosis in the heterozygous state. Blood. 71:508511.

23. Feo, C., N. Nossal, E. Jones, and M. Bessis. 1982. A new technique to explore red cell physiology: measurement of erythrocyte deformability as a function of osmolarity: results obtained by an osmotic-scan-ektacytometer with normal blood and hemolytic anemias. C. R. Acad. Sci. (Paris). 195:687-691.

24. Mohandas, N., C. M. Clark, B. P. Health, M. Rossi, L. Wolfe, S. Lux, and S. B. Shohet. 1982. A technique to detect reduced mechanical stability of red cell membranes: relevance to elliptocytic disorders. Blood. 59:768-774.

25. Laemmli, U. K. 1970. Cleavage of structural proteins during the assembly of the head of bacteriophage T4. Nature (Lond.). 227:680-685.

26. Ungewickell, E., and W. Gratzer. 1978. Self-association of human spectrin. A thermodynamic and kinetic study. Eur. J. Biochem. 88:379-385.

27. Dhermy, D., M.-C. Lecomte, M. Garbarz, C. Feo, H. Gautero, O. Bournier, C. Galand, A. Herrera, F. Gretillat, and P. Boivin, 1984. Molecular defect of spectrin in the family of a child with congenital hemolytic poikilocytic anemia. Pediatr. Res. 18:1005-1012.

28. Liu, S.-C., J. Palek, and J. T. Prchal. 1982. Defective spectrin dimer-dimer association in hereditary elliptocytosis. Proc. Natl. Acad. Sci. USA. 79:20722076.

29. O'Farrell, P. 1975. High resolution two-dimensional electrophoresis of proteins. J. Biol. Chem. 250:4007-4021.

30. Matsudaira, P. 1987. Sequence from picomole quantities of proteins electroblotted onto polyvinylidene difluoride membranes. J. Biol. Chem. 262:1003510038.

31. Saiki, R. K., D. H. Gelfand, S. Stoffel, S. J. Scharf, R. Higuchi, G. T. Horn, K. B. Mullis, and H. A. Erlich. 1988. Primer-directed enzymatic amplification of DNA with a thermostable DNA polymerase. Science (Wash. DC). 239:487-491.

32. Sanger, F., S. Nicklen, and A. R. Coulson. 1977. DNA sequencing with chain-terminating inhibitors. Proc. Natl. Acad. Sci. USA. 74:5463-5467.

33. Gyllensten, U. B., and H. A. Erlich. 1988. Generation of single-stranded DNA by the polymerase chain reaction and its application to direct sequencing of the HLA-DQA locus. Proc. Natl. Acad. Sci. USA. 85:7652-7656.

34. Saiki, R. K., T. L. Bugawan, G. T. Horn, K. B. Mullis, and H. A. Erlich. 1986. Analysis of enzymatically amplified $\beta$-globin and HLA-DQ $\alpha$ DNA with allele-specific oligonucleotide probes. Nature (Lond.). 324:163-166.

35. Lawler, J., J. Palek, S.-C. Liu, J. Prchal, and W. M. Butler. 1983. Molecular heterogeneity of hereditary pyropoikilocytosis: Identification of a second variant of the spectrin $\alpha$-subunit. Blood. 62:1182-1189.

36. Knowles, W. J., J. S. Morrow, D. W. Speicher, H. S. Zarkowsky, N. Mohandas, W. C. Mentzer, S. B. Shohet, and V. T. Marchesi. 1983. Molecular and functional changes in spectrin from patients with hereditary pyropoikilocytosis. J. Clin. Invest. 71:1867-1177.
37. Sahr, K. E., M. Garbarz, D. Dhermy, M.-C. Lecomte, P. Bovivin, P. Agre, K. Laughinghouse, A. Scarpa, T. Coetzer, J. Palek, et al. 1990. Use of the polymerase chain reaction for the detection and characterization of mutations causing hereditary elliptocytosis. In Cellular and Molecular Biology of Normal and Abnormal Erythroid Membranes. J. Palek and C. Cohen, editors. Alan R. Liss, Inc., New York. 201-210.

38. Sahr, K. E., P. Laurila, L. Kotula, A. L. Scarpa, E. Coupal, T. L. Leto, A. J. Linnebach, J. C. Winkelmann, D. W. Speicher, V. T. Marchesi, et al. 1990. The complete cDNA and polypeptide sequences of human erythroid $\alpha$-spectrin. $J$. Biol. Chem. 265:4434-4443.

39. Speicher, D. W., and V. T. Marchesi. 1984. Erythrocyte spectrin is composed of many homologous triple helical segments. Nature (Lond.). 311:177-180.

40. Marchesi, S. L., W. J. Knowles, J. S. Morrow, M. Bologna, and V. T. Marchesi. 1986. Abnormal spectrin in heredity elliptocytosis. Blood. 67:141-151.

41. Floyd, P. B., P. G. Gallagher, L. A. Valentino, M. Davis, S. L. Marchesi, and B. G. Forget. 1990. Heterogeneity of the molecular basis of hereditary pyropoikilocytosis and hereditary elliptocytosis associated with increased levels of the spectrin $\alpha \mathrm{I} / 74$ kilodalton tryptic peptide. Blood. 78:1364-1372.

42. Coetzer, T. L., K. Sahr, J. Prchal, H. Blacklock, L. Peterson, R. Koler, J. Doyle, J. Manaster, and J. Palek. 1991. Four different mutations in codon 28 of $\alpha$ spectrin are associated with structurally and functionally abnormal spectrin $\alpha^{1 / 74}$ in hereditary elliptocytosis. J. Clin. Invest. 88:743-749.

43. Tse, W. T., M.-C. Lecomte, F. F. Costa, M. Garbarz, C. Feo, P. Boivin, D. Dhermy, and B. G. Forget. 1990. Point mutation in the $\beta$-spectrin gene associated with $\alpha \mathrm{I} / 74$ hereditary elliptocytosis. Implications for the mechanism of spectrin dimer self-association. J. Clin. Invest. 86:909-916.

44. Pothier, B., L. Morle, N. Alloisio, M. T. Ducluzeau, C. Caldani, C. Feo, M. Garbarz, I. Chaveroche, D. Dhermy, M.-C. Lecomte, et al. 1987. Spectrin Nice $\left(\beta^{220 / 216}\right)$ : a shortened $\beta$-chain variant associated with an increase of the $\alpha^{1 / 74}$ fragment in a case of elliptocytosis. Blood. 69:1759-1765.

45. Garbarz, M., W. T. Tse, P. G. Gallagher, C. Picat, M.-C. Lecomte, F. Galibert, D. Dhermy, and B. G. Forget. 1991. Spectrin Rouen $\left(\beta^{200-218}\right)$, a novel shortened $\beta$-chain variant in a kindred with hereditary elliptocytosis: characterization of the molecular defect as exon skipping due to splice site mutation. J. Clin. Invest. 88:76-81.

46. Ohanian, V., J. P. Evans, and W. B. Gratzer. 1985. A case of elliptocytosis associated with a truncated spectrin chain. Br. J. Haematol. 61:31-39.

47. Eber, S. W., S. A. Morris, W. Schroter, and W. B. Gratzer. 1988. Interactions of spectrin in hereditary elliptocytoses containing truncated $\beta$-chains. $J$. Clin. Invest. 81:523-530.

48. Dhermy, D., M.-C. Lecomte, M. Garbarz, O. Bournier, C. Galand, H. Gautero, C. Feo, N. Allosio, J. Delaunay, and P. Boivin. 1982. Spectrin $\beta$-chain variant associated with hereditary elliptocytosis. J. Clin. Invest. 70:707-715.

49. Yawata, Y., A. Kanzaki, H. Wada, K. Ata, T. Inoue, J. Akatsuka, and J. Delaunay. 1990. A trait of $\beta$-spectrin variant HE (SP $\left.\beta^{220 / 216}\right)$ with hereditary elliptocytosis. Blood. 76:22A. (Abstr.)

50. Hoffman, N., P. Stanislovitis, P. C. Watkins, K. W. Klinger, A. J. Linnenbach, and B. G. Forget. 1987. Three RFLPs are detected by an alpha-spectrin genomic clone. Nucleic Acid Res. 15:4696.

51. Evans, J. P. M., A. J. Baines, I. M. Hann, I. Al-Hakim, S. M. Knowles, and A. V. Hoffbrand. 1983. Defective spectrin dimer-dimer association in a family with transfusion dependent homozygous hereditary elliptocytosis. Br. J. Haematol. 54:163-172.

52. Garbarz, M., M.-C. Lecomte, D. Dhermy, C. Feo, I. Chaveroche, H. Gautero, O. Bourner, C. Picat, A. Goepp, and P. Boivin. 1986. Double inheritance of an alpha $\mathrm{I} / 65$ spectrin variant in a child with homozygous elliptocytosis. Blood. 67:1661-1667.

53. Iarocci, T. A., G. M. Wagner, N. Mohandas, P. A. Lane, and W. C. Mentzer. 1988. Hereditary poikilocytic anemia associated with the co-inheritance of two alpha spectrin abnormalities. Blood. 71:1390-1396.

54. Lawler, J., T. L. Coetzer, V. N. Mankad, R. B. Moore, J. T. Prchal, and J. Palek. 1988. Spectrin $\alpha^{1 / 61}$ : a new structural variant of $\alpha$-spectrin in a double-heterozygous form of hereditary pyropoikilocytosis. Blood. 72:1412-1415.

55. Palek, J. 1987. Hereditary elliptocytosis, spherocytosis and related disorders: consequences of a deficiency or a mutation of membrane skeletal proteins. Blood Rev. 1:147-168. 